\title{
Enzymatic remediation of the polluted crude oil by Rhodococcus
}

\author{
Zhang Leilei ${ }^{\star}$, Huo Mingxin and Zhu Suiyi \\ School of Urban and Environmental sciences, Northeast Normal University, 5268 Renmin Street, Changchun, \\ Jilin Province, China.
}

Accepted 27 January, 2012

\begin{abstract}
A Rhodococcus strain was isolated from the activated sludge in oil field and its enzymatic remediation activity of crude oil was investigated. Potential impact of different levels of crude oil on activities of enzymes (dehydrogenase, catalase, urease and polyphenol oxidase) from this strain was studied after 120 days of continuous application. Enzyme activities were compared with microbial biomass samples and available samples. The activities of bacterial enzymes and degradation of various components of the crude oil were analyzed. The results showed that all the four enzymes were inhibited with the increase of crude oil concentration, and the components of crude oil were changed with the enzymes. After 120 days, the crude oil polluted- soil was well remediated and the enzymes could promote the microbiological degradation. Furthermore, the effect of different carbon sources on the biomass production of Rhodococcus strain was investigated.
\end{abstract}

Key words: Rhodococcus, dehydrogenase, catalase, urease, polyphenol oxidase, crude oil.

\section{INTRODUCTION}

As with the development of petroleum industry, the area of oil-polluted soil was enlarged continuously. Thus, it would come to a burning question to treat the oil-polluted soil to recovery level in a short period (Turgay et al., 2010). The bioremediation technology could be adopted because of its low cost, pollution-free, and high efficient characters. In recent years, this technology had a quick development and various microorganisms with special physiological and biochemical functions where screened, which promote the bioremediation technology for further application and development (Elshafie et al., 2007; Ayotamuno et al., 2006).

The oil-degrading microorganisms were widely distributed in the soils, which played an important role to remediate the polluted soils. It is remarkably effective to treat groundwater and soil polluted by tar and crude oil with the aid of aboriginal microorganisms. The crude oil permeated into soil by varying ways and interacted with soil enzymes (Azaizeh et al., 2011). On one hand, the

*Corresponding author. E-mail: yexiali@yahoo.com.cn. Tel: +8610-52853660. Fax: +8610-52853660. enzymes from oil-degrading microorganisms could be as an indicator for assaying the amount and physiochemical property of crude oil. On the other hand, the enzymes had the remarkable ability to degrade the petroleum. The activities of the enzymes indicated the tendency and intensity of various biochemical reactions, though the amounts of the enzymes were quite small. In a sense, the enzyme, a living molecular unified with the environment factors, could degrade the oil to simple chemical compounds. The degradation effect was related with the crude oil concentration and the species and amount of microorganisms in the soil (Gana et al., 2011). It is necessary and should be taken more attention to investigate the relationship between the enzymes from oil-degrading microorganisms and the environmental pollution and seek the suitable parameters of enzyme activity.

\section{MATERIALS AND METHODS}

Chemicals

All the chemicals used were of analytic reagent. 
Table 1. Experiment design of remediating the polluted cruel oil by bacteria.

\begin{tabular}{cll}
\hline Fo. & Concentration of crude oil $(\boldsymbol{\mu g} / \mathbf{k g})$ & Method of treating soil samples \\
\hline 1 & & (1) sterilization \\
2 & & (2) aboriginal microorganisms \\
3 & 30000 & (3) incubation of non-sterilized soil with bacteria \\
4 & (2) 15000 & (1) sterilization \\
5 & & (2) aboriginal microorganisms \\
6 & (3) incubation of non-sterilized soil with bacteria \\
7 & (3) 5000 & (1) sterilization \\
8 & & (2) aboriginal microorganisms \\
9 & & (3) incubation of non-sterilized soil with bacteria \\
\hline
\end{tabular}

\section{Isolation and identification of bacteria}

The isolated strain was phylogenetically identified by ITS-5.8S rDNA sequencing analysis. The chromosomal DNA of the strain was isolated from the fresh mycelium using a CTAB method (Reski et al., 1991). The resulting genomic DNA was amplified using $2 \times$ Taq MasterMix (CoWin Biotech Co.,China) and primers ITS1(5'TCC GTA GGT GAA CCT GCG G-3') and ITS4 (5'-TCC TCC GCT TAT TGA TAT GC-3') on an Applied Biosystems Veriti 96-well thermal cycler (Applied Biosystems, CA) under the following conditions: $94^{\circ} \mathrm{C}, 5 \mathrm{~min}(1 \mathrm{cycle}) ; 94^{\circ} \mathrm{C} 45 \mathrm{~s}, 55^{\circ} \mathrm{C} 50 \mathrm{~s}, 72^{\circ} \mathrm{C} 60 \mathrm{~s}$, (33 cycles); $72^{\circ} \mathrm{C} 5 \mathrm{~min}$ ( 1 cycle). The PCR products were sequenced in both directions by Sangon Biotech Co., Led (Shanghai, China).

The obtained nucleotide sequence of the ribosomal sequence was compared with those of GeneBank using the NCBI Blast program, and sequence homology was comparatively analyzed using the Clustal $X$ program. Consequently, the isolated strain was identified as Rhodcoccus sp. (GeneBank data homology search result $>99 \%$ )

\section{Soil sampling and preparation}

A bulk of soil sample was collected from the Muomuoge National Natural Reserve, Jilin, China. The soil was brought to the laboratory, air-dried, grinded and hand-picked to remove stones and discrete plant residues, passed through sieve and mixed thoroughly. The crude oil and dehydrated oil was received from Honggang oil extraction plant of Jilin oil field, Jilin Province, People's Republic of China. The component contents composed of $70.8 \%$ saturated hydrocarbon, $15.6 \%$ aronatic hydrocarbon, $10.9 \%$ non-hydrocarbon and $2.6 \%$ asphaltum.

A sub sample of the soil (1000 g) was taken and sterilized or incubated with bacteria according to Table 1 . Then every piece of soil samples was mixed with $6.7 \%$ wooden meal and $1.6 \%$ rice shell to increase the ventilation. Afterwards, the samples were transferred to $1000 \mathrm{ml}$ capacity glass beakers. The soil samples were added to $20 \mathrm{ml}$ nutritious salts $\left(\mathrm{NH}_{4} \mathrm{Cl} 2.5 \mathrm{~g}, \mathrm{KH}_{2} \mathrm{PO}_{4} 5 \mathrm{~g}\right.$, $\mathrm{MgSO}_{4} \cdot 7 \mathrm{H}_{2} \mathrm{O} 2.5 \mathrm{~g}$ and distill water $1000 \mathrm{ml}$ ) (DINGJIE BIOLOGICAL TECHNOLOGY Co., China) at 0, 20, 40, 60 and 80 days respectively, and then pre-incubated at $30^{\circ} \mathrm{C}$ and 30 to $50 \%$ water content for 120 days. Finally, the soil samples were air-dried, grinded and stored at $4^{\circ} \mathrm{C}$ (Table 1 ).

\section{Analysis of soil enzymes activity}

For analysis of soil urease activity, $5 \mathrm{~g}$ soil was taken into $50 \mathrm{ml}$ conical flask, and $10 \mathrm{ml}$ of $10 \%$ urea (DINGJIE BIOLOGICAL TECHNOLOGY Co., China) solution and $20 \mathrm{ml}$ citric acid buffer (pH 6.7) (DINGJIE BIOLOGICAL TECHNOLOGY Co., China) were added into flask. Soil sample was incubated at $37^{\circ} \mathrm{C}$ for $24 \mathrm{~h}$. After $24 \mathrm{~h}$, the solution was filtered and $0.5 \mathrm{ml}$ of filtrate was taken into $50 \mathrm{ml}$ vol. flask, and $20 \mathrm{ml}$ distilled water and $4 \mathrm{ml}$ of mixed reagent (Phenol $+\mathrm{NaOH})(3 \mathrm{~B}$ Pharmachem International Co., China) were added. Then, $4 \mathrm{ml}$ of sodium hypo chlorite solution was added, mixed and made the volume to $20 \mathrm{ml}$ with distilled water, and absorbance of color was measured at $578 \mathrm{~nm}$.

Catalase activity in soils was measured using the $\mathrm{KMnO}_{4}(3 \mathrm{~B}$ Pharmachem International Co.,China) titrimetric method. In brief, $3.0 \mathrm{~g}$ fresh soil was placed in $100 \mathrm{ml}$ measuring flask and $40 \mathrm{ml}$ distilled water and $5 \mathrm{ml}$ of $0.3 \% \mathrm{H}_{2} \mathrm{O}_{2}$ (DINGJIE BIOLOGICAL TECHNOLOGY Co., China) solution into flask which was shaken thoroughly for 20 min. $5 \mathrm{ml}$ of $3 \mathrm{~N} \mathrm{H}_{2} \mathrm{SO}_{4}$ (DINGJIE BIOLOGICAL TECHNOLOGY Co., China) was mixed to cease the reaction and the suspension was filtered. The residual $\mathrm{H}_{2} \mathrm{O}_{2}$ was determined by titration with $0.1 \mathrm{~N} \mathrm{KMnO}_{4}$. Catalase activity is expressed in milliliter ( $\mathrm{ml})$.

Soil dehydrogenase activity was measured by the reduction of triphenyl tetrazolium chloride (TTC) (Sigma-Aldrich,China) to triphenyl formazan (TPF). Briefly, $5 \mathrm{~g}$ soil sample was incubated for $20 \mathrm{~h}$ at $30^{\circ} \mathrm{C}$ in $2 \mathrm{ml}$ of $1 \%$ TTC solution). Two drops of conc. $\mathrm{H}_{2} \mathrm{SO}_{4}$ were immediately added after the incubation to stop the reaction. The sample was then blended with methanol (BOYUN BIOTECH Co., China) to extract TPF and shaken for $15 \mathrm{~min}$ at $150 \mathrm{rpm}$, followed by filtration, and the color absorbance of the extract was measured at $485 \mathrm{~nm}$.

For measurement of polyphenol oxidase activity, $1 \mathrm{~g}$ fresh soil samples were transferred into a $50 \mathrm{ml}$ measuring flask and mixed with $10 \mathrm{ml}$ of $1 \%$ pyrogallol (DINGJIE BIOLOGICAL TECHNOLOGY Co., China) solution. After incubation at $30^{\circ} \mathrm{C}$ for $3 \mathrm{~h}, 0.5 \mathrm{~mol} / \mathrm{L}$ ether was added into the mixture to $50 \mathrm{ml}$, and then shaken manually. The gallic acid produced was extracted with ether and measured spectrophotometrically at $430 \mathrm{~nm}$.

The enzyme activities of urease, dehydrogenase and polyphenol oxidase were quantified by reference to a calibration curve constructed using $\left(\mathrm{NH}_{3}\right)_{2} \mathrm{SO}_{4}$, TPF, and gallic acid (Sigma-Aldrich, China) standards, respectively. Soil urease, dehydrogenase, catalase and polyphenol oxidase activities were expressed as $\mathrm{NH}_{3}-\mathrm{Nmg} / \mathrm{g}, \mathrm{ml}$, TPF $\mathrm{ml}$, and $\mathrm{mg} / \mathrm{ml}$, respectively. Soil enzymes 


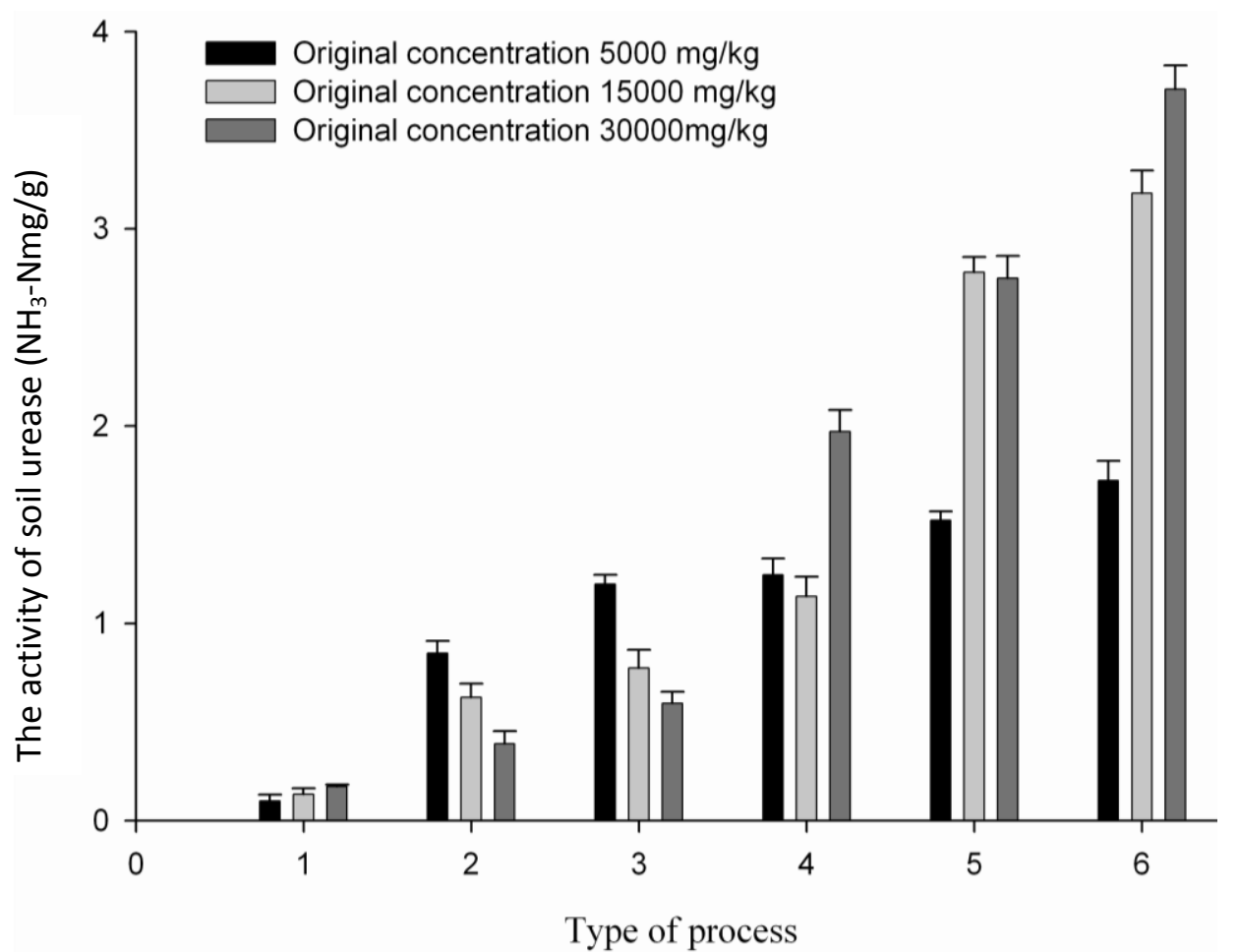

Figure 1. The activity of soil urease.1. Initial period and sterilization; 2. Initial period and treated by aboriginal microorganisms; 3 . Initial period, non-sterilized and treated by bacteria; 4. After 120 days and sterilization; 5 . After 120 days and treated by aboriginal microorganisms; 6. After 120 days, non-sterilized and treated by bacteria.

activity data for different treatments were analyzed by ANOVA and means $(n=3)$ with SPSS 7.0.

\section{Extraction, separation and analysis of main families of compounds present in crude oil}

Before experimentation and after bacterial degradation of the crude oil, the main families of compounds were analyzed in order to appreciate the variations in the initial composition. The separation of different families was achieved as following:

(1) The residual crude oil was extracted with $30 \mathrm{ml}$ chloroform DINGJIE BIOLOGICAL TECHNOLOGY Co., China) from $5 \mathrm{~g}$ soil. Then the extraction was filtrated.

(2) After solvent evaporation, the filtrate was mixed the $30 \mathrm{ml}$ petroleum ether $\left(30-60^{\circ} \mathrm{C}\right)$ and kept $12 \mathrm{~h}$ to deposit asphaltenes.

(3) By adding petroleum ether, the asphaltenes was separated by filtration. The soluabilized filtrate was concentrated to $3-5 \mathrm{ml}$ by circumfluence (<120 drops/min).

(4) The asphaltenes was dissolved in chloroform and evaporated.

(5) The asphaltene-free residue was introduced into a silica column (column height and diameter were 500 and $9 \mathrm{~mm}$, respectively). After six successive delution with $30 \mathrm{ml}$ petroleum ether, $5 \mathrm{ml}$ mixture of chloroform and petroleum ether $(2: 1)$ were selected to dilute the column to obtain composed of saturated hydrocarbons (first dilution) and aromatic hydrocarbons (second-fourth dilution).

(6) After fourth elution, the column was eluted by absolute alcohol and chloroform to obtain non- hydrocarbons.

(7) The various fractions were weight after kept at $40^{\circ} \mathrm{C}$ to removal of the solvent.

\section{RESULTS AND DISCUSSION}

\section{Effect of petroleum hydrocarbon on soil urease}

Urease was exited almost bacteria, fungi and higher plant. It is one kind of amidase, which could catalyze the hydrolysis of urea into carbon dioxide and ammonia. The activity of soil urease was positively correlated to the amount of microorganisms, organic material content, total nitrogen and available phosphorus (Chacón et al., 2009; Xue et al., 2006).

The influence of petroleum hydrocarbon on soil urease was shown in Figure 1. The activity of urease was enhanced corresponding to increase the concentration of the crude oil. Soil urease activity showed a significantly negative correlation $(P=0.002)$, which could be used as the most sensitive indicator of petroleum contamination (Li et al., 2005).

After biodegradation of $120 \mathrm{~d}$, the activity of soil urease in the crude oil $(30,000 \mu \mathrm{g} / \mathrm{kg})$ increased, especially the soil added bacteria, the activity of soil urease reached to $1.9716 \mathrm{NH}_{3}-\mathrm{Nmg} / \mathrm{g}$. There was no significant difference among the six soil samples of the same concentration, which showed the amount of microorganism had the influence to urease activity. Soil bacteria was increased with increasing soil TPH concentration, the CFU of soil bacteria was significantly correlated with soil $\mathrm{TPH}$ 


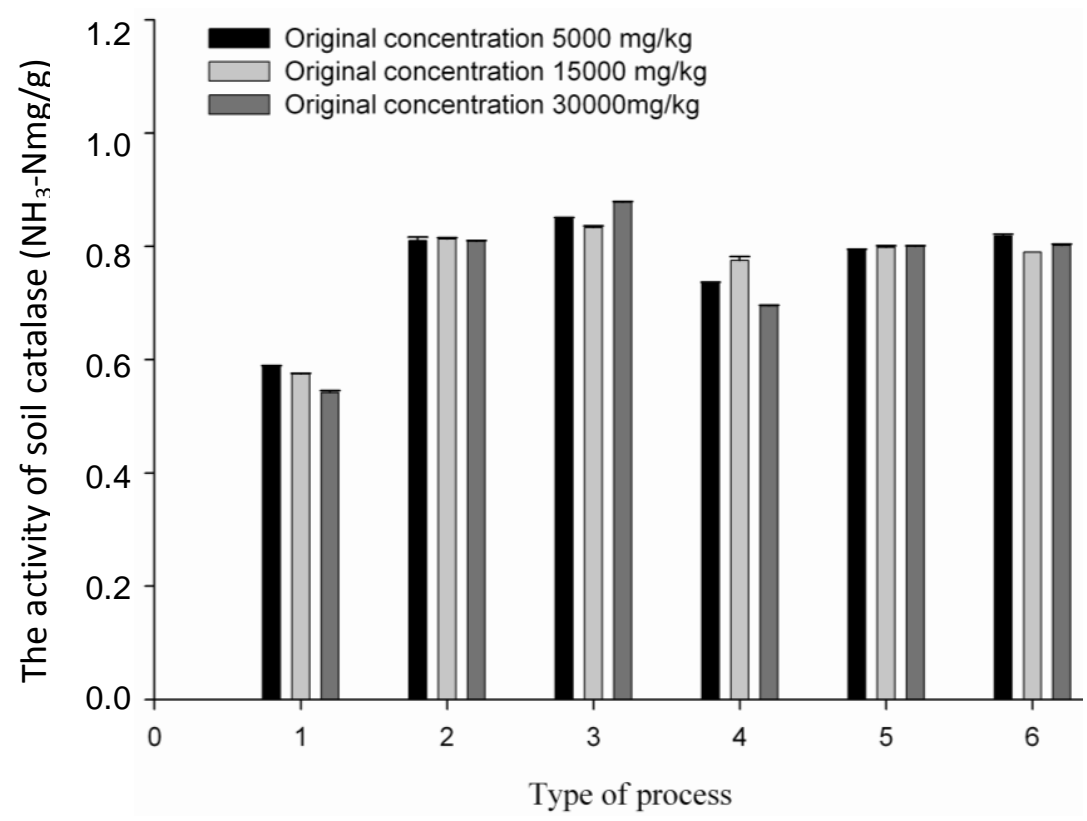

Figure 2. The activity of soil catalase.1. Initial period and sterilization; 2. Initial period and treated by aboriginal microorganisms; 3. Initial period, non-sterilized and treated by bacteria; 4 . After 120 days and sterilization; 5 . After 120 days and treated by aboriginal microorganisms; 6. After 120 days, non-sterilized and treated by bacteria.

concentration (Li et al., 2005). After $120 \mathrm{~d}$, the significant difference was observed between the soil samples added aboriginal microorganisms and bacteria, which indicate the microorganisms would affect the enzymatic activity.

\section{Effect of petroleum hydrocarbon on soil catalase}

Catalase is a common enzyme found in nearly all living organisms that are exposed to oxygen, where it catalyzes the decomposition of hydrogen peroxide to water and oxygen. Generally speaking, there was hydrogen peroxide of high level concentration in soil and the activity of catalase decreased with correspond increase in the concentration of polluted crude oil (Yu, 2008).

As shown in Figure 2, after 120 days, the catalase activities were decreased except sterilized soil samples, which indicate that the petroleum hydrocarbon inhibited the catalase activity, that is the toxic action during petroleum hydrocarbon degradation led to decrease the catalase activity. There was no significant difference between the soil samples incubated with aboriginal microorganisms and bacteria. The amount of microorganism was showed without significant influence on catalase activity. The catalase activity was increased in the phytoremediation areas (Shen et al., 2011).

That result indicated that during petroleum hydrocarbon degradation, more cataleses were consumed to degrade the petroleum with the increase the concentration of crude oil.

\section{Effect of petroleum hydrocarbon on soil dehydrogenase}

It reported that the concentration of crude oil had the significant effect on activity of soil dehydrogenase (Ueno et al., 2007), which also conformed in Figure 3. The soil dehydrogenase activities from the samples polluted by crude oil of higher concentration were higher than those polluted by crude oil of lower concentration. The reason perhaps was that some organic material in petroleum could increase the concentration of hydrogen ion, which led to increase the measurement value of dehydrogenase activity, instead of real enzyme activity. It need to further investigation whether the organic material in petroleum could invoke or increase the dehydrogenase activity.

Compared the dehydrogenase activity at initial phase and after 120 days, it was found that the petroleum could inhibit the dehydrogenase activity, and petroleum of higher concentration had stronger inhibition activity, especially the samples incubated with bacteria. However, the dehydrogenase activities had no difference in the samples incubated with original microorganisms, which indicated during petroleum hydrocarbon degradation, more dehydrogenase were consumed, or the ecological equilibrium of microorganisms was disrupted and led to the decrease of dehydrogenase production.

It was pointed out that there were no significant correlation between the dehydrogenase activity and soil microorganisms (Maeder et al., 2002). However, after degradation of 120 days, the enzyme activity in the soil 


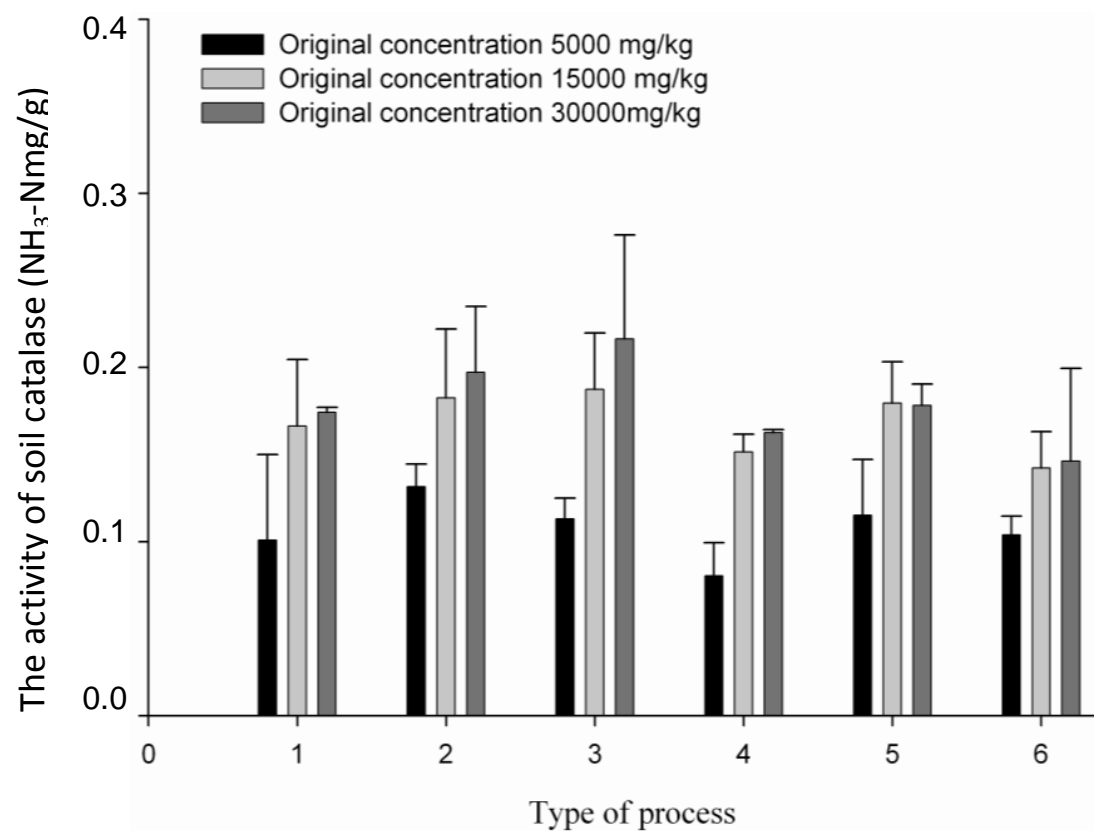

Figure 3. The activity of soil dehydrogenase.1. Initial period and sterilization; 2. Initial period and treated by aboriginal microorganisms; 3 . Initial period, nonsterilized and treated by bacteria; 4 . After 120 days and sterilization; 5. After 120 days and treated by aboriginal microorganisms; 6 . After 120 days, non-sterilized and treated by bacteria.

samples incubated with aboriginal microorganisms were higher than the samples of non-sterilized and treated by bacteria, while there was no difference between the sample sterilized and the samples of non-sterilized and treated by bacteria, which indicated there was irregular relationship between the amount of microorganism and dehydrogenase activity, it is different to the dehydrogenase in the soil polluted by petroleum spillage were also noticed (Wyszikowska and Kucharski, 2000).

\section{Effect of petroleum hydrocarbon on soil polyphenol oxidase}

Phenol oxidize could transform aromatic organic compounds in the humus. Generally, catalyze the oxidation of phenolic compounds to quinones, which could have the condensation with amino acid and peptide to form humilic acid. The activity of phenol oxidase had the negative correlation with humification degree of the humus (Lucas and Casper, 2008). Thus, determination of phenol oxidase activity could aid to understand the humification degree of the humus. As showed in Figure 4, the phenol oxidase activities were quite different in the samples polluted by the crude oil of different concentration. The activities of phenol oxidase increased almost in the soil samples with the different treatments except sterilized soil samples. It was indicated that after 120 days, the humification degree of the humus decreased and was related with microorganism growth inhibited by crude oil.

\section{Petroleum hydrocarbon degradation in soil}

As showed, the natural degradation percentage of crude oil was quite small without incubation of microorganism (Table 2). It was only about $10 \%$ after treatment of 120 days. Original microorganisms had the ability to degrade the crude oil though the ability is quite low and only could degrade saturated hydrocarbon. Thus, it is far from enough to self-clean the crude oil pollution in the soil. Whereas, the degradation percent of the soil samples incubated with bacteria is quite higher than the other two treatments. The degradation percent of saturated hydrocarbon even reached to more than $80 \%$ in the soil samples incubated with bacteria. The activities of microorganisms in soil were inhibited because of the polluted crude oil. Both aromatic hydrocarbon and nonhydrocarbon were degraded in the soil samples incubated with Rhodococcus whereas hardly consumed by microorganism. And the degradation percentages were higher than the soil samples incubated with original microorganisms. It is indicated that the bacteria had the strong ability to degrade the crude oil in the soil efficiently.

In this study, as clean soil was mixed with crude oil artificiality. The microorganisms were difficult to adapt to the soil microbial environment and its activity was inhibited when the oil concentration increased suddenly. Meanwhile the tested soils were wetland meadow soil with higher nutrient, and original microorganisms would prefer organic matter which is easy to be decomposed as 


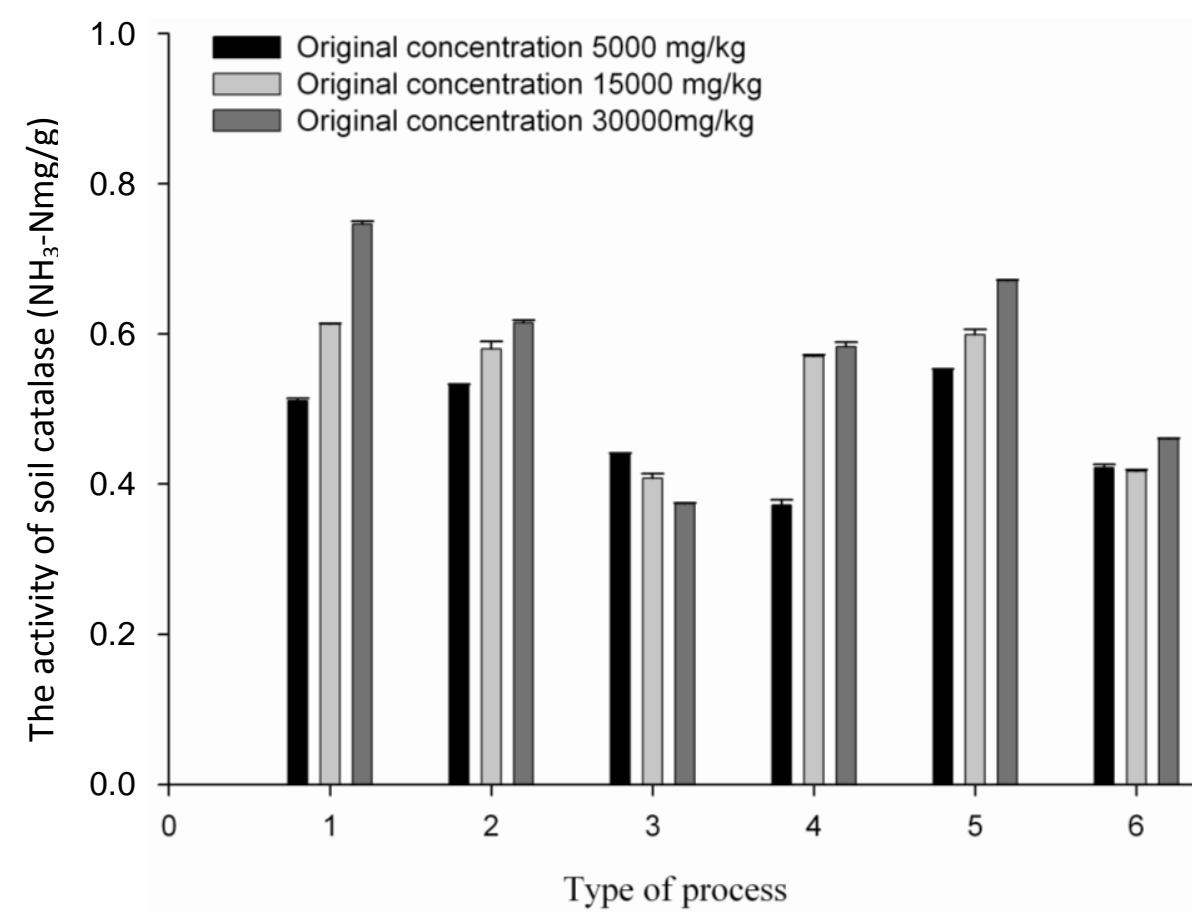

Figure 4. The activity of soil polyphenol oxidase.1. Initial period and sterilization; 2. Initial period and treated by aboriginal microorganisms; 3 . Initial period, non-sterilized and treated by bacteria; 4 . After 120 days and sterilization; 5 . After 120 days and treated by aboriginal microorganisms; 6 . After 120 days, non-sterilized and treated by bacteria.

Table 2. Petroleum hydrocarbon degradation in soil after 120 days.

\begin{tabular}{ccccc}
\hline No. & $\begin{array}{c}\text { Saturated hydrocarbon } \\
\text { degradation (\%) }\end{array}$ & $\begin{array}{c}\text { Aronatic hydrocarbon } \\
\text { degradation (\%) }\end{array}$ & $\begin{array}{c}\text { Non-hydrocarbon } \\
\text { degradation (\%) }\end{array}$ & $\begin{array}{c}\text { Asphaltum } \\
\text { degradation (\%) }\end{array}$ \\
\hline 1 & 10.00 & 0.00 & 5.00 & 0.79 \\
2 & 14.43 & 8.33 & 27.72 & 7.04 \\
3 & 73.82 & 19.66 & 19.69 & 12.19 \\
4 & 21.94 & 1.64 & 5.71 & 1.52 \\
5 & 27.67 & 0.00 & 15.00 & 10.01 \\
6 & 77.33 & 49.32 & 20.51 & 13.57 \\
7 & 9.72 & 14.29 & 9.25 & 0.00 \\
8 & 37.07 & 12.12 & 13.27 & 8.33 \\
9 & 81.69 & 46.43 & 28.56 & 16.67 \\
\hline
\end{tabular}

growth substrate.

The contaminated soil with low concentrations effected microorganisms slightly and inhibited their activity with low level.

Three different concentrations of the control conditions, bacteria can significantly improve the components of crude oil in soil removal. Vaccination exogenous bacteria can effectively promote the degradation of crude oil in soil.

In this study, simulated repair experimental results showed that the screened strains could coexist with original microorganisms in contaminated soil, and could effectively promote degradating the various components of crude oil in soil. Applying of this conclusion, it is feasible that polluted soil can be repaired.

\section{Effect on carbon source on bacterial biomass production}

To investigate the effect of carbon source for biomass production, three hydrocarbon carbon sources (liquid paraffin, n-hexadecane and cyclohexane) were provided at a concentration level of $0.5,0.3,0.6 \mathrm{~g} / \mathrm{L}$ respectively 


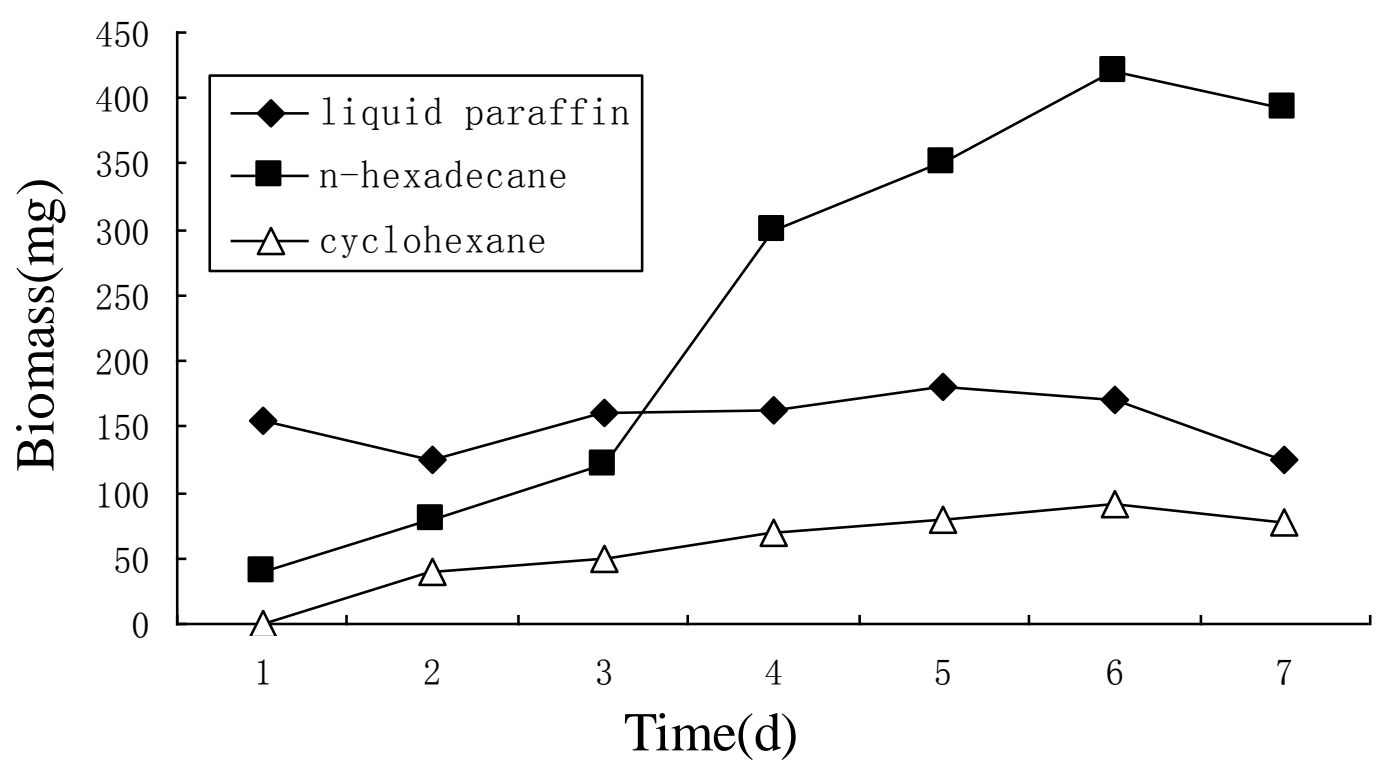

Figure 5. Effect on carbon source on bacterial biomass production.

for $7 \mathrm{~d}$, at $120 \mathrm{r} / \mathrm{min}$ and $30^{\circ} \mathrm{C}$. Samples collected periodically from shake flasks were centrifuged at 10,000 $\mathrm{r} / \mathrm{min}$ for $10 \mathrm{~min}$ to obtain biomass. The dry weight of biomass was measured after drying at $90^{\circ} \mathrm{C}$ for overnight so as to obtain constant weight. The results indicated the bacteria had the different ability to utilize the different hydrocarbon sources. The maximum biomass production was reached to $393 \mathrm{mg}$ when $\mathrm{n}$-hexadecane was employed. When the liquid paraffin was added in the medium, the biomass yield increased rapidly, after first day the cells entered their stationary phase, which indicated the bacteria could only utilized part of carbon source from liquid paraffin. It is hard to suggest that cyclohexane was supplied as carbon source, because the final biomass is markedly lower than that cultured in n-hexadecane.

(Figure 5)

\section{Conclusion}

This study investigated the biodegradation of crude oil by Rhodococcus and the activities of soil enzymes in degradation. The soil enzymes activities from Rhodococcus (dehydrogenase, catalase, urease and polyphenol oxidase) under the different conditions after 120 days of bioremediation were investigated. The bacterial stains screened showed good abilities of promoting degradation. In this study, the correlation between the four soil enzymes and degradation of crude oil polluted soil was clarified. It was showed that the degradation results were quite different as the different treatments were applied. The correlation experiments showed that the activity of soil urease was an important indicator of the crude oil polluted degree. Further, it is indicated that the bacteria have the different utilization ability for different hydrocarbon carbon sources. This study would provide the theoretic basis for the bioremediation of crude oil polluted marsh.

\section{ACKNOWLEDGEMENT}

Thanks to International Center of Papertrans (http://www.papertrans.cn/) for the revision of the manuscript.

\section{REFERENCES}

Ayotamuno MJ, Kogbara RB, Ogaji SOT, Probert SD (2006). Bioremediation of a crude-oil polluted agricultural-soil at Port Harcourt. Niger. Appl. Energ., 83: 1249-1257.

Azaizeh H, Castro PML, Kidd P (2011). Biodegradation of Organic Xenobiotic Pollutants in the Rhizosphere. Org. Xenobiotics and Plants., 8: 191-215.

Chacón N, Herrera I, Flores S, González JA, Nassar JM (2009). Chemical, physical, and biochemical soil properties and plant roots as affected by native and exotic plants in Neotropical arid zones. Biol. Fertil. Soils., 45: 321-328.

Elshafie A, AlKindi AY, Al-Busaidi S, Bakheit C, Albahry SN (2007). Biodegradation of crude oil and $n$-alkanes by fungi isolated from Oman. Mar Pollut. Bull., 54: 1692-1696.

Gana ML, Kebbouche-Gana S, Touzi A, Zorgani MA, Pauss A, Lounici $\mathrm{H}$, Mameri N (2011). Antagonistic activity of Bacillus sp. obtained from an Algerian oilfield and chemical biocide THPS against sulfatereducing bacteria consortium inducing corrosion in the oil industry. $\mathrm{J}$. Ind. Microbiol. Biotechnol., 38: 391-404.

Li H, Zhang Y, Zhang CG, Chen GX (2005). Effect of PetroleumContaining Wastewater Irrigation on Bacterial Diversities and Enzymatic Activities in a Paddy Soil Irrigation Area. J. Environ. Qual., 34: 1073-1080.

Lucas RW, Casper BB (2008). Ectomycorrhizal community and extracellular enzyme activity following simulated atmospheric $\mathrm{N}$ deposition. Soil Biol. Biochem., 40: 1662-1669.

Maeder P, Fliessbach A, Dubois D, Gunst L, Fried P, Niggli U (2002). 
Soil Fertility and Biodiversity in Organic Farming. Science, 296: 16961697.

Reski R, Wehe M, Hadeler B, Marienfeld JR, Abel WO (1991). Cytokinin and light quality interact at the molecular level in the chloroplastmutant PC22 of the moss Physcomitrella. J. Plant Physiol., 138: 236243.

Shen YY, Wang WK, Li CR, Guan XK, Wang XX (2011). Research on soil catalase activity for petroleum contaminations. Water Resour. Environ. Protect., 4: 1855-1858.

Turgay OC, Erdogan EE, Karaca A (2010). Effect of humic deposit (leonardite) on degradation of semi-volatile and heavy hydrocarbons and soil quality in crude-oil-contaminated soil. Environ. Monit. Assess., 170 : 45-58.
Ueno A, Ito Y, Yumoto I, Okuyama H (2007). Isolation and characterization of bacteria from soil contaminated with diesel oil and the possible use of these in autochthonous bioaugmentation. World J. Microbiol. Biotechnol., 23: 1739-1745.

Wyszikowska J, Kucharski J (2000). Biochemical properties of soil contaminated by petroleum. Environ. Stud., 9:.479 - 485.

Xue D, Yao HY, Huang CY (2006). Microbial Biomass, N Mineralization and Nitrification, Enzyme Activities, and Microbial Community Diversity in Tea Orchard Soils. Plant Soil., 288: 319-331.

Yu FQ (2008). Effects of mycorrhiza symbiosis on the enzyme activities in the rhizosphere. University of Inner Mongolia Agriculture. People's Republic of China. 